FACTA UNIVERSITATIS

Series: Law and Politics Vol. 18, No 3, 2020, pp. 147-160

https://doi.org/10.22190/FULP2003147V

Original Scientific Paper

\title{
IS THE LINK BETWEEN SERBIAN LOCAL GOVERNMENTS' PUBLIC POLICY GOALS AND LOCAL CIVIL SERVANTS' PERFORMANCE GOALS STRONG ENOUGH?
}

UDC 352.07

$321.022: 342.25$

\section{Dejan Vučetić, Predrag Dimitrijević}

Faculty of Law, University in Niš, Serbia

\begin{abstract}
This paper attempts to explain and connect two separate processes in Serbian local governments. The first process pertains to the development of local public policies goals, which has recently been completely regulated by the Planning System Act (2018). The second process refers to the evaluation of performance of local civil servants, which is thoroughly regulated by the Decree on evaluation of civil servants (2019). Our main thesis is that public policy goals can be more than just a mere wish list only if there is a "clear and present" link between these two processes. The authors explain the basic features of local development plans, mid-term plans, local public policy documents (strategies, programs, action plans) and the performance appraisal system of local civil servants. In particular, Article 7 of the Decree on evaluation of civil servants (2019) provides the starting point for the inclusion of public policies goals into local servants 'performance goals. However, for this connection to be put into effect, there are many other things that need to be changed in the local government regulation and organizational culture.
\end{abstract}

Key words: local government, public policies, performance evaluation, local civil servants, work goals

Received November $20^{\text {th }} 2020 /$ Accepted December $1^{\text {st }}, 2020$

Corresponding author: DejanVučetić, LL.D., Associate Professor, Faculty of Law, University of Niš, , Trg Kralja Aleksandra 11, 18000 Niš, Serbia. E-mail: dvucetic@prafak.ni.ac.rs

* The paper is the result of research within the ERASMUS + project Interdisciplinary Short Cycle Programs in Public Policy Making and Analysis (PPMA), which is funded by the European Commission (Project No 598596EPP-1-2018-1-RS-EPPKA2-CBHE-JP). The paper reflects the authors' views only, and the Commission cannot be held responsible for any use which may be made of the information contained therein. 


\section{INTRODUCTORY REMARKS}

The principle of coherence is very often put aside when good governance doctrine is analyzed, although it is set as one of the five basic elements of Good Governance in the EU White paper on Good Governance (2001). ${ }^{1}$ This article aims to provide an answer to this question why we insist on that principle. First, the public sector system is becoming increasingly complex and hard to coordinate and cooperate. As noted by Osborne and Gaebler (1992), in the context of increased public sector complexity, the role of the state is to be the helmsman of the state ship not a rower (Colebatch, 2004:123). In the context of the modern $21^{\text {st }}$ century government, it implies changing the former paradigm that public administration should follow only the paths of legality and the rule of law and, in line with Good Governance doctrine, include efficacy and effectiveness as the upper governing layer in contemporary states and societies.

The next question is how this relates to the Serbian local government system. Since the outset of the $21^{\text {st }}$ century, the competencies of Serbian local government units have constantly been expanded. It is in line with the tendency towards differentiation and multiplication of public functions and bodies, which is well documented in many textbooks on public administration (Petrović, 2011: 89-96; Pusić, 2002: 83). But, to successfully coordinate all of its functions (new and the old ones), another very important local government function has been introduced within the scope of Serbian local governments' competencies -the planning function.

Although the planning function was originally introduced in the 2002 Local Government Act, the Local Government Act $(2007)^{2}$ envisaged that local governments are in charge of planning, managing, and governing public matters within their scope of competences and of interest for local citizens. But, this function was not thoroughly regulated, and it was performed in accordance with the sectoral laws regulating environmental issues, construction issues etc., which yielded poor results.

A decade later, the Planning System Act $(2018)^{3}$ finally regulated the planning duties of local self-governments units in Serbia in more detail. ${ }^{4}$ Article 1 of this Act regulates the planning system of the Republic of Serbia, i.e. policy system management and mediumterm planning, the types and content of the proposed planning documents, adopted and implemented by planning system participants in accordance with their respective mandates, and mutual consistency of planning documents. Thus, the regulatory environment for the local public policy making was finalized. It considers the key aspects of social and economic, regional, and spatial development policies, with optimal and sustainable use of local public resources (Radomirović, Aleksić, Marinković, 2020: 5). Besides the Planning System Act (PSA), the basic package of planning system regulations includes several decrees, the most important of which are: the Decree on public policy management, policy and regulatory impact assessment, and content of individual public policy documents (hereinafter: the Public Policy Decree) $)^{5}$ and the Decree on methodology for the development of mid-term plans (hereinafter: the Decree on mid-term planning). ${ }^{6}$

\footnotetext{
${ }^{1}$ European Commission, European Governance - a White Paper, 25 July 2001, COM(2001) 428 final.

${ }^{2}$ Official Gazette of RS, No. 129/2007, 83/2014 - another law, 101/2016 - another law and 47/2018.

${ }^{3}$ Official Gazette of RS, no. 30/2018.

${ }^{4}$ This Act regulates the planning obligations of all key subject in the public sector, such as: state authorities, autonomous provinces authorities, and local government authorities.

${ }^{5}$ Official Gazette of RS, no. 8/2019.

${ }^{6}$ Official Gazette of RS, no. 8/2019.
} 


\section{2, ON THE PROCESS OF PUBlic POLICY GoAls SETting IN LOCAL SELF-GOVERNMENTS IN SERBIA}

Prior to the adoption of the Planning System Act (2018), which set the standards for the process of public policy making and implementation, public policy documents were very often enacted without the clear goals, or with overlapping goals, or without measures for promoting the goals, etc. Also, no effects were analyzed in the planning process, and the whole process was not coordinated with the local government budget. Numerous misconducts were present in the consultancy process with relevant stakeholders, along with the low transparency of actions. In most local governments, the systems for monitoring the implementation of public policies goals were underdeveloped.

It has all changed since 2018. From a regulatory standpoint, the Planning System Act and the accompanying regulations have enabled better coordination, more extensive citizen involvement, better effects evaluation and measurements, and reporting on the implementation of these documents. For the first time, Serbia has gained a methodological framework for public policies development and implementation with precise classification of public policy documents. This refers to the national and the local level alike.

In order to understand how the local governments' goals are set and defined, we must first explain the basic types and characteristics of the public policy documents, such as: development planning documents, public policy documents, and other planning documents. According to the PSA, development planning documents are: the development plan, the investment plan, the spatial plan of the Republic of Serbia, other spatial and general urban plans, the development plan of the autonomous province, and development plans of the local self-government units.

\subsection{Local development plan}

Acting upon the proposal made by the city or municipal council, the local assembly enacts the local development plan as a long-term planning document. The local development plan (LDP) covers a seven-year period. The city or municipal council should make a draft report on the effects of the implementation of the development plan every third year. This draft report should be approved and adopted by the local assembly. This plan is an umbrella document for all other local public policy and planning documents, which means that all other local public policies and documents must comply with it. At the moment of writing of this paper, the Planning System Act still envisages that local development plans should

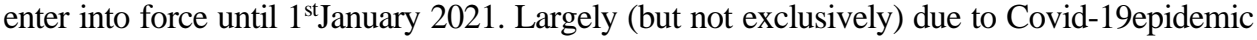
problems, it is almost certain that most of the local government units will breach this deadline.

Mandatory elements of local government development plans were precisely defined in August 2020, when the Serbian Government enacted the Decree on mandatory elements of the development plan of the autonomous province and local self-government units. $^{7}$ According to Article 2 of this Decree, every local development plan must contain the following six elements: introduction, overview and analysis of the current state of affairs, vision, the most important development goals, review and description of measures for achieving the goals, and measures for monitoring and implementation.

${ }^{7}$ Official Gazette RS, 107/2020. 
The introduction of the local development plan should include the following obligatory elements: data on the time of its making, subjects of public policy process, consultations with the relevant stakeholders, and the way they were conducted.

The overview and the analysis of the current situation should include the following elements: review of the existing social, economic, environmental, and infrastructural situation in the local government unit. This should be done by using relevant (selected) quantitative indicators. This part contains the review of development potentials and obstacles to growth of the local unit. All this should be put in the context of and connected with the relevant public policies of the Republic of Serbia, ${ }^{8}$ as well as the international initiatives, especially the European ones, which are important for the local communities and their development.

Vision, as the necessary element of the local development plan, is basically the statement in which a local government describes the situation that is to be achieved in the future upon realization of the LDP development goals.

The fourth part of the LDP defines the so-called priority development goals. It describes the situation that is to be achieved in certain areas of local affairs during its validity, and it ensures that those goals are in compliance with relevant national and provincial public policy goals. Those goals are defined in the Development Plan, the Investment Plan, and the Spatial and Urban Plan of the Republic of Serbia. In case those goals are to be further elaborated in other public policy documents, this part of the LDP should contain guidelines for making such documents. These goals should also be coordinated with the local General Urban Plan, General Regulation Plan, and Detailed Regulation Plans.

The next part of the LDP establishes and defines the performance indicators (their initial and target values), as well as the timelines for achieving these goals and sources of information for verification of their values. Priority development goals should be defined according to the SMART methodology (specific, measurable, achievable, relevant, timebound) and in accordance with sovereign competences of Serbian local government units. ${ }^{9}$ It is of utmost importance that these goals are real, clear and achievable, which enables their further transmission into the local civil servants and officials performance goals. Those goals should be in accordance with the goals and principles of sustainable development established through the international global framework presented in the 2030 Agenda for Sustainable Development (UN 2015), titled Transforming Our World, which was adopted by the UN General Assembly on $25^{\text {th }}$ September 2015 and will be in force until 2030. The 2030 UN Agenda sets the Sustainable Development Goals which are transformative, citizen-centered and rights-based, and oriented towards ending poverty and protection of our planet. The Agenda 2030 has set 17 basic goals and 169 sub-goals related to three dimensions of sustainable development: economic, social and environmental; it also includes about 240 accompanying indicators to measure progress in achieving the Sustainable Development Goals. Many of those indicators are applicable to the local development goals and can be included into local development plans. Given that these indicators can be used as the LDP indicators, the Serbian Bureau of Statistics is trying to measure as many of these indicators as possible (Radomirović, Aleksić, Marinović, 2020: 15).

\footnotetext{
${ }^{8}$ It also applies to the policies and planning documents of the autonomous province, if the local government unit is on the territory of the autonomous province.

${ }^{9}$ According to Appendix 11 of the Decree on Methodology of Public Policy Management there are 17 self regulated areas of local governments competences with 37 subareas.
} 
The fifth part of the LDP should define all measures for the achievement of the LDP goals, especially if no other public policy document that is hierarchically lower than LDP is to be made. The fifth part should include types and names of the measures, how they will contribute to the achievement of the development goals, activities necessary for implementing the measures, analysis of the effects that the measures will have on individuals, legal entities and the local budget, the specific bodies responsible for coordinating the implementation of the measures, and the assessment of the financial expenses and other necessary financial resources. Those measures are further developed and implemented through the medium-term plan, by the organizational unit of the local government responsible for budget or public funds. The performance goals of the local public officials and civil servants that are accountable for the implementations of these measures should be directly connected with these exact measures! In the Decree, these local officials and servants are called "measure bearers"; this ill-devised term (and its undefined content) can be misinterpreted and, more importantly, it may cause numerous misunderstandings concerning the poor implementation or non-implementation of these measures, without clearly specified accountability for such outcomes.

To avoid such outcomes, local governments need to continually monitor the implementation of goals and measures, using predefined methods of data gathering from all local bodies and authorities that are accountable for the implementation of LDP measures. These methods can be divided into twogroups:1) methods for gathering data necessary for the measures implementation, and 2) methods for enlisting the achieved results. Of course, there are other data gathering methods that will show if measures are successfully implemented (databases available at the websites of the Republic Public Policies Secretariat and the Republic Bureau of Statistics, questionnaires, interviews and focus groups) but local governments cannot rely solely on third party data.

In that context, the civil servants who manage internal local units have the most important role. The job descriptions in the Rulebook on internal organization and systematization of the local governments should clearly state personal accountability for gathering and processing the data necessary for monitoring the implementation of local development plans. This clearly shows the importance of precisely defined roles and responsibilities in the local civil service system. The personal responsibility for data gathering and processing should subsequently be included in the annual performance goals of these officials and servants, after including these responsibilities in the local administration's Rulebook on internal organization and systematization. That is the link that has to be established in order for public policy goals to be implemented. This issue will be discussed in more detail later on in this paper.

The sixth part of the LDP should define the methods for monitoring the implementation. The most important elements of these methods are the institutional framework for implementation data, the assessment of minimally required financial and material sources, and how they are to be acquired, and the possible ways for the verification of results.

Finally, in addition to the six mandatory parts, a local development plan can include annexes. According to Article 3 of the Decree, the annexes may provide more detailed and comprehensive overview of the local data, as well as ex post analysis of relevant planning documents, data on stakeholder consultations, etc. The only mandatory annex is the one providing details on the conducted consultations. ${ }^{10}$

\footnotetext{
${ }^{10}$ It includes detail on the participants, the period in which consultations were conducted, the methods used, specific remarks and suggestions which were (not)accepted, and statements why the suggestions were not accepted.
} 


\subsection{Local public policy documents}

Public policy documents are planning documents by which participants in the planning system determine or elaborate already established public policies. The types of policy documents are: strategies, programs, policy concepts, and action plans.

According to the PSA, development planning document is the highest-ranking planning document, and is used by local governments for setting goals and priorities of public policies, and setting measures and activities for their realization.

\subsubsection{Strategy}

A strategy is a basic local public policy document, which is used for comprehensive determination of strategic direction of local public policy actions in certain areas of public policy planning and implementing of public policies. According to Article 12 of the PSA, there are two basic types of strategies: 1) sector-oriented strategies, in which case policies are formulated for a specific sector; and 2) cross-sectoral strategies, in which case public policies are determined for a number of planning fields. A crosssectoral strategy is made in case there is a need to achieve long-term goals in several mutually related fields of local life, by applying a wide range of related activities. Both types of strategies are made for a five to seven-year period.

All strategies include some necessary elements. According to Article 13 of PSA, these elements are: vision (desired state of affairs), overview and analysis of current state of affairs, general and specific public policy goals which are to be achieved, measures for achieving both types of goals, analysis of the effects of these measures, key performance indicators ${ }^{11}$ for both types of goals, institutional framework for their implementation, implementation overview and a plan for evaluating performance, reporting on the realized measures, etc. As a strategy needs to be appropriately focused, the PSA envisages that each strategy should have only one general and up to five specific goals. The PSA allows for the possibility of defining more goals, but it should be explained by the entity that is proposing the strategy.

\subsubsection{Action plan}

The realization of strategic goals is monitored in accordance with the action plan for the strategy implementation. The action plan should be part of the Strategy; it is made and adopted at the same time as the strategy or, exceptionally, no longer than 90 day after the strategy has entered into force. Given that local governments (unlike the national authorities) are not required to adopt action plans, they must replace it with the so-called mid-term plan, which is connected to the LDP. This duty is envisaged in Article 26 of the PSA. A mid-term plan is made in compliance with the local budget decision (financial plan) and covers the same three-year period that is covered by the local budget decision. ${ }^{12} \mathrm{~A}$ mid-term plan should also be adopted on an annual basis, following the adoption of the local budget decision. ${ }^{13} \mathrm{~A}$

\footnotetext{
${ }^{11}$ These indicators measure the efficacy and effectiveness of planned public policies formulated within the strategy.

${ }^{12}$ The decision has the fiscal projection for the next two years, in line with the budget year.

${ }^{13}$ The Decree on the Methodology for the Development of Mid-term Plans (Official Gazette RS, No. 8/2019) regulates the methodology of mid-term planning, the content of the mid-term plan, the process of its development and adoption,
} 
mid-term plan is adopted by the local assembly. But, if a mid-term plan is developed by individual users of budgetary or public funds, then the mid-term plan has to be adopted by the managing officials of these bodies. Mid-term planning of measures and activities and midterm financial planning are unified processes that take place continuously throughout the year, and the deadlines for the key steps in these unified processes are determined by the Budget System Act, ${ }^{14}$ the PSA and the Decree on the Methodology for the Development of Mid-term Plans. This Decree elaborates in detail on the manner of determining general and specific objectives, measures, accompanying performance indicators and activities, and provides the formats of all the elements that make the mid-term plan. Based on the aforesaid, it may be concluded that effective coordination and communication of civil servants engaged in local self-government who oversee these (development and financial planning) processes is crucial for the successful implementation of local public policies. Program budgeting is of crucial importance for this issue as well, but its detailed analysis exceeds the scope of this paper.

\subsubsection{Program}

A program is a public policy document of a narrower scope, which is focused only on one specific goal (previously defined in the strategy or some other hierarchically higher public policy document) and aimed at specifying and developing means and ways for its achievement. A program includes several measures and projects which should jointly be applied to achieve the specified goal. Otherwise, if each measure or project is used separately (without coordination), it would be hard (if not impossible) to achieve the goal. One program should contain up to three sub-goals, each of which can directly contribute to the achievement of the specified goal. A program lasts for a shorter period than a strategy (for a three-year period maximum) and contains the same elements as a strategy, especially the developed measures for achieving the goal, explained in detail. If the measures are fully developed and defined, then the enactment of a separate action plan is not necessary. Under the PSA, besides the public policy documents, all participants in the planning process are obliged to adopt other planning documents, such as mid-term plans and financial plans.

Another important part of the PSA is dedicated to public policy measures, their concept and types. It is particularly relevant because it is the precondition for their proper designation in local public policy documents. Under Article 24 of the PSA, a measure is defined as a set of key and interconnected activities that need to be undertaken for the public policy to take desired effects or for the specific goal to be achieved. Measures are divided into several subtypes: 1) regulatory measures, if they set standards or rules to administer social relations; 2) incentives, which are divided into fiscal measures (subsidies, taxes, etc.), other financial measures, and non-financial measures; 3) informative and educational measures; 4) institutional and organizational measures(establishment of new or abolishment of existing bodies, internal organizational structure changes, changes of number and competencies of local officials, civil servants and employees, etc.); 5) provision of public good and services by the participants in the public policy process (such as: public investments, capital and infrastructure projects, etc.).

the manner and deadline for its publication, implementation, monitoring, evaluation, and reporting on the implementation of that plan, and its content and implementation for the previous fiscal year.

${ }^{14}$ Official Gazette of RS, no. 54/2009, 73/2010, 101/2010, 101/2011, 93/2012, 62/2013, 63/2013-correction, 108/2013, 142/2014, 68/2015-another law, 103/2015, 99/2016, 113/2017, 95/2018, 31/2019 and 72/2019. 
It is very important for the local governments' highest officials to always have the bigger picture in mind, i.e. that their public policy documents have to be in compliance with the public policy documents of the Republic of Serbia, or in compliance with the documents of the autonomous province if the local government is situated on the territory of the province. Next, the local public policy documents must be harmonized with the main financial documents such as the budget. Above all, they must be harmonized and operationalized with the operative performance goals and plans of actions of the local government civil servants, which is often neglected. We will address this issue in the concluding part of the paper but, first, we have to explain how the goals of local officials and civil servants are defined and implemented.

\subsection{Institutional framework of public policies planning at the local level}

Most of the Serbian local government units have not yet fully developed their operational institutional framework, the organizational and civil servants' capacities for achieving all public policy functions and goals. It is necessary to ensure the Rulebook on systematization and organization of local government units includes at least one full-time post (position) pertaining to the performance of the planning function in the context of public policy making and analyzing activities, coordinating the strategic planning, implementing development strategies, analyzing effects and reporting on the strategy implementation. Jobs descriptions most similar to the aforesaid functions can be found in the jobs descriptions of civil servants working in the internal units for economic development in Serbian local governments or in the sector for budgetary analysis. The institutional framework would not be complete without key stakeholders from the local community, such as a permanent working group or a coordinating team.

\section{The Process of Setting Performance Goals for Public OfFicials AND CIVIL SERVANTS IN SERBIAN LOCAL GOVERNMENTS}

The process of defining the performance goals of the local civil servants and public officials is part of the broader concept of performance management mechanism and public administration reform doctrines such as New Public Management and Good Governance (Pollit, Bouchaert, 2017). Performance management assessment of activities of local personnel, as a type of New Public Management mechanism, was introduced into Serbian local government legislation rather late, with the adoption of the 2016 Employees in Autonomous Provinces and Local Self-Government Act (hereinafter: the Employees Act). ${ }^{15}$ This change came a full decade after a similar system was introduced into the state public administration (Lončar, Vučetić, 2013). The provisions of the Employees Act were further developed by the adoption of several decrees: the Decree on Coefficients for Calculation and Payment of Salaries of nominated and appointed persons and employees in state bodies; ${ }^{16}$ the Decree on Job Classification and Job Description Criteria for Officials in Autonomous Provinces and Local Self-Government Units; ${ }^{17}$ the Decree on Job Classification and Job Description Criteria for Employees in Autonomous Provinces

\footnotetext{
${ }^{15}$ Official Gazette RS, No.4/2016, 113/2017, 113/2017 -another act, 95/2018.

${ }^{16}$ Official Gazette of RS, No. 44/2008-consolidated text, 2/2012, 113/2017-another act, 23/2018 and 95/2018repealed by another act.

${ }^{17}$ Official Gazette of RS, No. 88/2016, 113/2017-another act and 95/2018-another act.
} 
and Local Self-Government Units; ${ }^{18}$ the Decree on the Procedure for Obtaining Consent for new employment and additional employment for users of public funds; ${ }^{19}$ the Decree on the Implementation of Internal and Public Competition for filling vacancies in autonomous provinces and local self-government units; ${ }^{20}$ the Decree on the Internal Labor Market of State Bodies $;^{21}$ and the Decree on the Evaluation of Officials. ${ }^{22}$

By enacting these regulations, the modern human resources management system in Serbian local governments has almost completely been established. The missing part is the Act on Salaries of Civil Servants and State Employees in the Autonomous Province Bodies and Local Self-Government Units, ${ }^{23}$ which was enacted in 2017 but has not entered into force yet.

New mechanisms that have been introduced are: flexibility of organization, mobility within the whole public administration system, promotion based on merits, professionalism, transparency, accountability, etc. Human resources functions have been strengthened and made wider with tools such as human resource planning, competitive and objective selection of candidates based on merits and transparent criteria, job classification system based on professional performance, promotion based on merit, professional development, training needs analysis, coherent professional training system, and new performance appraisal system (Vukašinović-Radoičić, Vučetić, 2017: 256). One of those tools is evaluation of quality and quantity of local public officials and civil servants' activities, aimed at assessing the degree of achieving the previously agreed performance goals. This type of assessment is also called the performance appraisal.

According to Article 3 of Decree on Evaluation of Civil Servants, which is applicable to the local servants as well, a civil servant is evaluated once in a calendar year for the period from January 1 to December 31, provided that the civil servant's activities are monitored during the entire evaluation period. The performance results and previously set performance goals are evaluated quarterly in the evaluation report. The supervising head of local administration (civil servant in position) who decides on the rights, obligations and responsibilities of the local civil servants shall issue (by the end of February of the current year at the latest) an administrative decision on determining the achieved grade for the evaluation period. This administrative decision concerning the evaluation of the head of the administration and the deputy head of the administration (civil servants in position) shall be made by the mayor, or the president of the municipality or the president of the city municipality.

The evaluative decision is usually based on the evaluation report prepared by the civil servant that is directly superior to the evaluated local civil servant, but in certain cases it can be made by the local public officials or the appointing body of the local selfgovernment, which are usually called appraisers. In the evaluation procedure, their activities are directly controlled and confirmed by the signature of the local civil servants called controllers. During the evaluative period, the appraiser should constantly monitor the activities of the subordinated local servants, and collect data (note, record and comment on relevant examples) and evidence on their work efficiency, having in mind several

\footnotetext{
${ }^{18}$ Official Gazette of RS, No. 88/2016.

${ }^{19}$ Official Gazette of RS, No. 113/2013, 21/2014, 66/2014, 118/2014, 22/2015 and 59/2015.

${ }^{20}$ Official Gazette of RS, No. 95/2016.

${ }^{21}$ Official Gazette of RS, No. 88/2019.

${ }^{22}$ Official Gazette of RS, No. 2/2019.

${ }^{23}$ Official Gazette of RS, No. 113/2017 and 95/2018.
} 
factors: the nature of their activities, working conditions and prior work experience. On a quarterly basis, the supervisor should evaluate the civil servant's performance results against the goals that are set at the beginning of the year.

Performance results make $50 \%$ of the overall grade, and they are usually qualified as a quantitative part of the grade. The second part of the grade are the so-called qualitative elements of the grade: independence, creativity, entrepreneurship, precision and conscientiousness, cooperation with other local employees, and other job-related skills required by the specific position. These qualitative elements of the grade are defined in Articles $12-18$ of the Decree. Independence is a criterion demonstrating the capacity to achieve the performance goals with the minimum amount of instructions and supervision of the assessors, and in line with the civil servant's position in the local government hierarchy (job title). Creativity is a criterion used to assess a local civil servant's capacity to think analytically and creatively, and evaluate facts and circumstances when making decisions or suggestions for solving problems. Entrepreneurship shows a local civil servant's capacity to plan and put into effect the work goals within the powers and responsibilities envisaged in the job description, without special instructions from the assessor. Accuracy and conscientiousness show a local civil servant's capacity to perform his/her duties in a meticulous, correct and timely manner. The quality of cooperation shows a civil servants capacity for effective and harmonious work and contacts with superiors, equals and subordinates in his internal unit, as well as the capacity to connect and coordinate his/her actions with civil servants from other internal units of the local body where he/she works and from other local government bodies, services and organizations. Additional assessment criteria may be defined in case of the need for assessing job-related skills required by the specific position. They are determined in advance for the specific assessment period.

The basic grades are defined in Article 19 of the Decree and elaborated in detail in subsequent provisions. The grading scale includes the four categories: "unsatisfactory" (1); "satisfactory" (2); "good" (3); and "outstanding" (4).

Comparatively speaking, there is no single widely-accepted model for the assessment of civil servants' performance. Generally, there are two possible models: the first is based on predetermined criteria and, thus, it is easier to use; the second (which is applied in Serbia) is based on the mutually agreed performance goals, which is often "a complex and timeconsuming process” (Vukašinović-Radoičić, Rabrenović, Korać, 2018: 63). The application of the latter type of performance appraisal in state administration for more than a decade has shown certain aberrations, such as the inflation of highest grades embodied in "the tendency to award high grades for the sake of maintaining (good) work atmosphere" (Vukašinović-Radoičić, Rabrenović, Korać, 2018: 63), and the essential ineffectiveness of this assessment method. Public servants still consider performance appraisal to be an unnecessary bureaucratic procedure! Unfortunately, these same aberrations are starting to emerge in the local governments performance appraisals as well.

In the context of the subject matter of this paper, now we come to the most important part of the Decree, designated as "Presumptions for assessment". According to Article 7 of the Decree, a minimum of three and a maximum of five work goals shall be set within an evaluation period to every civil servant who is eligible for assessment. Here, we come to the first problem. If we take a look at the average Rulebook on the systematization and internal organization of an average local self-government in Serbia, the job description for a civil servant post usually contains more functions that should be performed by a single civil 
servant during a year (the number of functions is often two, three or even more times larger than the maximum of five goals envisaged for performance appraisal). This is the consequence of the ongoing process of constantly adding new duties to the existing ones and, in some cases, even cutting down the "local government workforce". This problem has intensified in the past couple of years because of the state-wide employment ban, which is still in force. It is part of a larger organizational problem pertaining to a systemic disproportion in the (increasing) number of functions of local governments and the (decreasing) number of employees that should perform these functions. The number of jobs per local civil servant (as a typical local government employee) by far exceeds the optimum of three to five job tasks, especially in small local government units. ${ }^{24}$

\section{The Link Between Public Policy Goals and Performance Goals OF LOCAL CIVIL SERVANTS}

The second paragraph of Article 7 of the Decree on evaluation of civil servants (2019) is crucial for our research question. In order to be achievable and measurable, and to have realistic deadlines, "Performance goals must arise from planning and other documents related to the activities of the body, organization or service, as well as job descriptions and purposes..." (Article 7 of the Decree). This clearly shows that the Serbian legal system has the legal basis for establishing the direct link between the public policy goals and yearly performance targets of local civil servants. But, it is a completely different question whether the appraisers actually comply with that provision when setting the performance goals of local civil servants in practice. Unfortunately, we have to say that the answer is negative! This conclusion is based on the wide-spread practice that will be explained in the following lines.

Performance goals are usually set according to legal obligations that arise from certain acts of the judicature, without considering the public policies and the documents that formulate them. This approach is more pertinent to the continental legal systems traditions, based on the strong concept of the rule of law and the legal state. But, we need to change the this view and adopt a more "Anglo-Saxon approach" (Vukašinović-Radoičić, Rabrenović, Korać, 2018:66), according to which a strong connection between public policy goals and civil servants' performance appraisal needs to be established. ${ }^{25}$

Another reason for this kind of wide-spread practice is the fact that the public policy and strategic documents are obsolete; they contain outdated goals and measures which are not in accordance with the changed state of affairs, the conditions for public administrative actions, or the real capacities for their implementing. That is why public policy documents must be constantly adapted and changed in accordance with the changed internal and external circumstances under which the local government is operating.

\footnotetext{
${ }^{24}$ These insights are based on the authors' personal experience gained through years of cooperative work and realization of numerous projects in Serbian local governments, as well as on some of the internal documents of the Ministry of state government and local-self-government that we have had an opportunity to access them.

${ }^{25}$ In recent times, France and Bulgaria have adopted this approach as well. |
} 


\section{CONCLUSION: \\ Two PARTS OF THE SAME Process INSTEAD OF THE Two SEPARATE WORLDS}

After providing a thorough analysis of the legal framework considering both the local public policy and planning framework, outlining the public policy goals and the legal framework for evaluating the performance of local civil servants, and discussing the crucial connection between the two systems, we will briefly give some concluding remarks.

First, linking the civil servants' individual goals and organizational and public goals is one of several notable trends in modern civil service systems. It has started gaining ground only recently in the continental legal systems, whereas it has long been in force in common law countries. This link is part of broader concepts of the New Public Management and Good Governance, and its validity is crucial for the successful accomplishment of public policy goals. Inclusion of public polices goals and measures in everyday performance targets of local civil servants is the only way for local civil servants to constantly remain committed to achieving these goals. In addition to appropriate setting of performance targets and goals of local civil servants, it calls for constant changes of Rulebooks on systematization and internal organization of local government and inclusion of public policies goals into the provisions of those Rulebooks. The second best solution would be to introduce (at least) a general formulation of local civil servants' duty to constantly work on achieving the local public policies goals. Those changes are the necessary preconditions for the final change of the local organization culture, which would generate a more proactive organizational planning culture.

Future changes of the regulatory framework are also necessary, in order to formally connect public policy goals with the performance goals of local civil servants. It is the only way to prevent the current situation in which civil servants are getting all the best grades, while many of the envisaged public policy goals are not being achieved, or their achievement is being substantially delayed. Clear accountability mechanisms need to be established, especially for the civil servants positioned in the higher levels of local hierarchy.

On the other hand, each public policy document should contain more details on operational issues for the implementation of the envisaged measures. It requires special knowledge about the functions and mechanisms of the local administration civil service. Those details mean the operationalization of goals down to the last civil servant, and his/her duty to implement them.

At the end, we propose legislation changes that will synchronize the cycles of performance evaluation of public polices with the performance evaluation of local civil servants who are accountable for the implementation of public policy goals.

\section{REFERENCES}

European Commission (2001). European Governance - a White Paper. Luxembourg: Publications Office of the European Union

Colebatch, Hal K. (2004). Policy. Zagreb: Fakultet političkih znanosti.

Lončar, Z., Vučetić, D. (2013). European Standards and Public Administration Reform in the Republic of Serbia,16th Toulon-Verona Conference "Excellence in Services", Ljubljana: University of Ljubljana. 434-454.

Osborne B., Gaebler, T. (1992). Reinventing government. Reading: MA: Addison-Wesley.

Petrović, M. (2011). Nauka o upravljanju kao pretpostavka upravne politike (opšti deo) - 2. ispravljeno izdanje. Niš: Sven samoizd.

Pollit, C., Bouchaert, G., (2017). Public management reform: a comparative analysis - new public management, governance, and the Neo-Weberian state. Oxford: Oxford University Press. 
Pusić, E. (2002). Nauka o upravi. Zagreb: Školska knjiga.

Radomirović, M., Aleksić, D., Marinović, A. (2020). Smernice za izradu planova razvoja jedinica lokalne samouprave. Beograd: Deutsche Gesellschaft für Internationale Zusammenarbeit (GIZ) GmbH.

United Nations (2015). Sustainable Development, Transforming our world: the 2030 Agenda for Sustainable Development A/RES/70/1, (accessed on 27.9.2020) https://www.un.org/ga/search/view_doc.asp?symbol= $\mathrm{A} / \mathrm{RES} / 70 / 1 \&$ Lang $=\mathrm{E}$

Vukašinović-Radoičić, Z., Vučetić, D. (2017). Novelties in the Serbian Local Self-Government System. In: Simenunović-Patić, B. (ed.) Archibald Reiss Days - thematic conference proceedings of international significance - Vol. II. Belgrade: Academy of Criminalistic and Police Studies.

Vukašinović-Radoičić, Z.; Rabrenović, A.; Korać, S. (2018). Performance Appraisal of Civil Servants Comparative Perspectives. In: Simović, D. (ed.) Archibald Reiss Days: thematic conference proceedings of international significance, Vol. II, Belgrade: Academy of Criminalistic and Police Studies. 61-72.

\section{LEGAL SOURCES}

Zakon o budžetskom sistemu (Budget System Act), Službeni glasnik RS, br. 54/2009, 73/2010, 101/2010, 101/2011, 93/2012, 62/2013, 63/2013 - ispr., 108/2013, 142/2014, 68/2015 - dr. zakon, 103/2015, 99/2016, $113 / 2017,95 / 2018,31 / 2019$ i 72/2019.

Zakon o lokalnoj samoupravi (Local Government Act), Službeni glasnik RS, 129/2007, 83/2014 - other law, $101 / 2016$ - dr. zakoni 47/2018

Zakon o planskom sistemu (Planning System Act), Službeni glasnik RS, 30/2018

Zakon o zaposlenima u autonomnim pokrajinama i jedinicama lokalne samouprave (Employees of Autonomous Provinces and Local Self-government Act), Službeni glasnik RS, 21/2016, 113/2017, 95/2018 i $113 / 2017$ dr. zakon.

Uredba o metodologiji upravljanja javnim politikama, analizi efekata javnih politika i propisa, i sadržaju pojedinačnih dokumenata javnih politika (Decree on Public Policy Management, Policy and Regulatory Impact Assessment, and Content of Individual Public Policy Documents), Službeni glasnik RS, 8/2019.

Uredba o metodologiji za izradu srednjoročnih planova (Decree on Methodology for the Development of Midterm Plans), Službeni glasnik RS, 8/2019.

Uredba o internom tržištu rada državnih organa (Decree on the Internal Labor Market of State Bodies), Službeni glasnik $R S, 88 / 2019$.

Uredba o obaveznim elementima plana razvoja autonomne pokrajine i jedinice lokalne samouprave (Decree on Mandatory Elements of the Development Plan of the autonomous province and local self-government units), Službeni glasnik RS, 107/2020.

Uredba o ocenjivanju službenika (Decree on the Evaluation of Officials), Službeni glasnik RS, 2/2019.

Uredba o kriterijumima za razvrstavanje radnih mesta i merilima za opis radnih mesta službenika u autonomnim pokrajinama i jedinicama lokalne samouprave (Decree on Job Cassification and Job Description Criteria for officials in autonomous provinces and local self-government units), Službeni glasnik RS, 88/2016, 113/2017 - dr. zakon, 95/2018 - dr. zakoni 86/2019 - dr. zakon).

Uredba o koeficijentima za obračun i isplatu plata imenovanih i postavljenih lica i zaposlenih u državnim organima (Decree on coefficients for calculation and payment of salaries of named/nominated and appointed persons and employees in state bodies), Službeni glasnik RS, 44/2008 - prečišćen tekst, 2/2012, $113 / 2017$ - dr. zakon, 23/2018, 95/2018 - dr. zakoni 86/2019 - dr. zakon.

Uredba o postupku za pribavljanje saglasnosti za novo zapošljavanje I dodatno radno angažovanje kod korisnika javnih sredstava (Decree on the Procedure for Obtaining Consent for new employment and additional employment with/for users of public funds), Službeni glasnik RS, 113/2013, 21/2014, 66/2014, $118 / 2014,22 / 2015$ i 59/2015.

Uredba o razvrstavanju radnih mesta i merilima za opis radnih mesta državnih službenika, (Decree on Job Classification and Job Description Criteria for employees in autonomous provinces and local selfgovernment units), Službeni glasnik RS, 88/2016.

Uredba o sprovođenju internog i javnog konkursa za popunjavanje radnih mesta u autonomnim pokrajinama $\mathrm{i}$ jedinicama lokalne samouprave (Decree on the Implementation of Internal and Public Competition for filling vacancies in autonomous provinces and local self-government units), Službeni glasnik RS, 95/2016. 


\section{DA LI JE VEZA IZMEĐU CILJEVA JAVNIH POLITIKA SRPSKIH LOKALNIH SAMOUPRAVA I RADNIH CILJEVA LOKALNIH SLUŽBENIKA DOVOLJNO JAKA?}

Ovaj rad pokušava da objasni i poveže dva odvojena procesa u srpskim lokalnim samoupravama. Prvi proces odnosi se na razvoj ciljeva lokalnih javnih politika, koji je nedavno u potpunosti regulisan Zakonom o planskom sistemu (2018). Drugi postupak odnosi se na ocenu učinka lokalnih službenika, koji je temeljno regulisan Uredbom o ocenjivanju službenika (2019). Naša glavna teza je da ciljevi javnih politika mogu biti više od puke liste želja samo ako postoji ,jasna i potpuna" veza između ova dva procesa. Autori objašnjavaju osnovne karakteristike lokalnih razvojnih planova, srednjoročnih planova, dokumenata lokalnih javnih politika (strategije, programi i akcioni planovi) $i$ sistema utvrđivanja radnih ciljeva lokalnih službenika. Konkretno, član 7. Uredbe o ocenjivanju službenika (2019) pruža polaznu osnovu za uključivanje ciljeva javnih politika u radne ciljeve lokalnih službenika. Međutim, da bi ova veza mogla da se realizuje, postoji mnogo drugih stvari koje treba promeniti u regulativi lokalne samouprave i njenoj organizacionoj kulturi.

Ključne reči: lokalna samouprava, javne politike, lokalni službenici, ocenjivanje učinka službenika, radni ciljevi 